\title{
ANALISA PERBANDINGAN BIAYA PEMBUATAN PELAT BETON SISTEM KONVENSIONAL DENGAN SISTEM BOUNDECK PADA PEMBANGUNAN GEDUNG KULIAH BERSAMA POLITEKNIK NEGERI FAKFAK
}

\author{
Muhammad Yunus, Budi Djatmiko \\ Jurusan Teknik Sipil, Politeknik Negeri Fakfak \\ Jl. TPA Imam Bonjol Atas Air Merah, Kelurahan Wagom Kabupaten Fakfak \\ Email: muhammadyunus@polinef.id ${ }^{1}$
}

DOI: http://dx.doi.org/10.29103/tj.v10i2.286

(Received: March 2020 / Revised: July 2020 / Accepted: August 2020)

\begin{abstract}
Abstrak
Dengan adanya kemajuan teknologi yang semakin pesat dalam dunia konstruksi, memungkinkan pengelola proyek untuk memilih salah satu metode pelaksanaan konstruksi tertentu dari beberapa alternatif metode pelaksanaan konstruksi yang ada. Salah satu usaha yang dilakukan oleh pengelola proyek adalah mengganti cara-cara konvensional menjadi lebih modern, hal ini memunculkan inovasi sistem pelat menggunakan boundeck sebagai alternatif lain dari sistem pelat konvensional. Tujuan dalam penelitian ini adalah untuk menganalisa perbandingan Rencana Anggaran Biaya (RAB) antara pekerjaan pelat beton dengan sistem konvensional dengan pekerjaan pelat beton sistem boundeck, pada Pembangunan Gedung Kuliah Bersama Politeknik Negeri Fakfak. Dari hasil penelitian yang dilakukan diperoleh anggaran biaya pekerjaan pelat beton dengan sistem konvensional sebesar Rp. 5.174.957.000,00 sedangkan anggaran biaya pekerjaan pelat beton dengan sistem boundeck sebesar Rp. 5.476.603.000,00. Selisih anggaran biaya dari kedua metode pelaksanaan pekerjaan pelat beton sebesar Rp. 301.646.000,00, di mana anggaran biaya pekerjaan pelat beton dengan sistem konvensional lebih ekonomis dibandingkan dengan anggaran biaya pekerjaan pelat beton dengan sistem boundeck.
\end{abstract}

Kata kunci: Pelat beton sistem konvensional, pelat beton sistem boundeck, rencana anggaran biaya, analisa harga satuan.

\begin{abstract}
With the rapid technological advances in the construction world, it allows project managers to choose one particular method of construction implementation from several alternative methods of implementation of existing construction. One of the efforts undertaken by the project manager is to replace conventional methods to become more modern. This led to the innovation of plate systems using floordeck as an alternative to conventional plate systems. The aims of this study was to analyze the comparison of the Budget Plan (RAB) between the work of concrete slabs with conventional systems with concrete slab with floordeck method, on the Construction of the Joint Lecture Building at the State Polytechnic of Fakfak. From the results of the research, the budget obtained for the work of concrete slabs using conventional systems is Rp. 5,174,957,000.00 while the budget for the work of concrete slabs with the boundeck system is Rp. 5,476,603,000.00. The difference in the budget for the cost of the two methods for carrying out concrete slabs is Rp. 301,646,000.00, where the
\end{abstract}

Analisa Perbandingan Biaya Pembuatan Pelat Beton Sistem Konvensional Dengan Sistem Boundeck Pada Pembangunan Gedung Kuliah Bersama Politeknik Negeri Fakfak - Muhammad Yunus, Budi Djatmiko 
budgetary work for concrete slabs with conventional systems is more economical than the budgetary work for concrete slabs with boundeck systems

Keywords: concrete slabs with conventional systems, concrete slab with floordeck system, budget plan, unit price analysis.

\section{Latar Belakang}

Pada masa sekarang ini, industri konstruksi merupakan suatu industri ekonomi nasional yang berhubungan dengan persiapan lahan dan pembangunan, percepatan, perbaikan bangunan, struktur, dan properti lain. Sejalan dengan perkembangan waktu, industri konstruksi menjadi suatu industri yang menjadi penyokong kehidupan suatu bangsa (Widiasanti \& Lenggogeni, 2013).

Perkembangan teknologi konstruksi saat ini mengalami kemajuan pesat yang ditandai dengan hadirnya berbagai jenis material maupun peralatan yang modern. Dengan adanya kemajuan teknologi yang semakin pesat dalam dunia konstruksi, memungkinkan pengelola proyek untuk memilih salah satu metode pelaksanaan konstruksi tertentu dari beberapa alternatif metode pelaksanaan konstruksi yang ada. Salah satu usaha yang dilakukan oleh pengelola proyek adalah mengganti cara-cara konvensional menjadi lebih modern. Hal ini memunculkan inovasi pembuatan pelat lantai beton menggunakan sistem boundeck sebagai alternatif lain dari sistem pelat konvensional (Uji, Wisal, \& Latif, 2012).

Penggunaan sistem boundeck sebagai pelat lantai umumnya karena memiliki lebih banyak keuntungan dibanding menggunakan pelat konvensional. Pemasangan boundeck tergolong cepat karena boundeck berfungsi sebagai bekisting tetap yang tidak perlu dilepas dan penulangan positif satu arah (tulangan tarik) dan pemakaian wiremesh sebagai tulangan tekannya. Sedangkan pelat konvensional perlu menggunakan bekisting dan menunggu 28 hari sampai masa pemeliharan beton selesai dan membutuhkan banyak kawat bendrat untuk merakit tulangannya. Pemakaian bondek juga dapat menghemat penggunaan scaffolding dibanding pelat konvensional. Pelat bondek juga dapat menghemat waktu pengerjaan dan material yang digunakan (Gursal, Tjakra, \& Mangare, 2018).

Perhitungan pelat lantai ini tidak lepas dari perhitungan Rencana Anggaran Biaya (RAB) dan waktu pelaksanaan pekerjaan. Perhitungan RAB dan waktu pekerjaan pada gedung ini bertujuan untuk mengetahui biaya yang dikeluarkan dan bahan ataupun alat yang digunakan serta jumlah pekerja yang dibutuhkan juga waktu pekerjaan yang dibutuhkan. Anggaran biaya ini harus dihitung dengan teliti, cermat dan memenuhi syarat-syarat yang ada. Perhitungan RAB ini mencakup perhitungan volume pekerjaan yang didapat dari gambar rencana, harga satuan upah dan bahan serta analisa harga satuan pekerjaan yang dikeluarkan per wilayah oleh pemerintah Indonesia ataupun dari SNI (Gursal et al., 2018).

Di daerah Papua Barat khususnya Kabupaten Fakfak jarang ditemukan pembangunan infrastruktur gedung menggunakan sistem boundeck, sering sekali di Kabupaten Fakfak masih menggunakan cara yang sederhana yaitu sistem konvensional. Untuk dapat menentukan sistem mana yang lebih murah maka perlu di lakukan perbandingan antara sistem boundeck dan sistem konvensional agar dapat digunakan sebagai bahan acuan dalam menentukan sistem yang akan

Analisa Perbandingan Biaya Pembuatan Pelat Beton Sistem Konvensional Dengan Sistem Boundeck Pada Pembangunan Gedung Kuliah Bersama Politeknik Negeri Fakfak - Muhammad Yunus, Budi Djatmiko 
digunakan pada pembangunan sebuah kontruksi. Pembangunan Gedung Kuliah Bersama Politeknik Negeri Fakfak dapat dijadikan sebagai tempat penelitian yang saat ini masih dalam proses pembangunan dengan menggunakan sistem boundeck di mana pelat boundeck sendiri harus didatangkan dari luar kota karena di Kabupaten Fakfak belum tersedia pelat boundeck. Tujuan dari penelitian ini adalah untuk menganalisa perbandingan biaya pekerjaan pembuatan pelat lantai dengan menggunakan sistem konvensional dan sistem boundeck.

\section{Metode Penelitian}

\subsection{Waktu dan Tempat Penelitian}

Penelitian ini dilaksanakan di lokasi Pembangunan Gedung Kuliah Bersama Politeknik Negeri Fakfak di Jl. Imam Bonjol Atas, Air Merah, Wagom, Distrik Pariwari, Kabupaten Fakfak, Provinsi Papua Barat. Waktu penelitian dilakukan 6 bulan yakni dari bulan Maret sampai dengan bulan Agustus 2019.

\subsection{Sumber Data}

Dalam penelitian ini, data yang digunakan ada 2 (dua) jenis sumber data yaitu:

1. Data Primer

Data primer yang digunakan dalam penelitian ini adalah hasil wawancara langsung dengan pihak pelaksana pekerjaan konstruksi Gedung Kuliah Bersama Politeknik Negeri Fakfak.

2. Data Sekunder

Data sekunder yang digunakan dalam penelitian ini antara lain, data Detail Engineering Design (DED), data Bill of Quantity (BoQ) Pembangunan Gedung Kuliah Bersama data Daftar Harga Bahan dan Upah Kabupaten Fakfak Tahun 2019, Analisa Harga Satuan Pekerjaan sesuai SNI (Standar Nasional Indonesia).

\subsection{Teknik Analisa Data}

Teknik analisa data yang digunakan dalam penelitian ini dengan tahapan sebagai berikut:

1. Mempelajari Gambar DED (Detail Engineering Design) Pembangunan Gedung Kuliah Bersama Politeknik Negeri Fakfak.

2. Mengestimasi volume pekerjaan pelat lantai sistem konvensional dan sistem boundeck sesuai dengan gambar DED (Detail Engineering Design) tiap-tiap section Gedung Kuliah Bersama Politeknik Negeri Fakfak.

3. Mengidentifikasi tiap item-item pekerjaan pada pekerjaan pembuatan pelat lantai beton baik sistem konvensional maupun sistem boundeck.

4. Menyusun analisa harga satuan tiap item-item pekerjaan dengan menggunakan metode analisa SNI (Standar Nasional Indonesia) tahun 2008 dan tahun 2016 untuk pekerjaan pelat lantai sistem konvensional dan sistem boundeck.

5. Memasukkan harga satuan bahan dan upah Kabupaten Fakfak tahun 2019 sesuai dengan analisa harga satuan yang telah disusun untuk tiap item-item pekerjaan pembuatan pelat beton sistem konvensional dan sistem boundeck.

6. Menyusun Rencana Anggaran Biaya (RAB) pekerjaan tiap item-item pekerjaan pada pembuatan pelat lantai beton sistem konvensional dan sistem boundeck.

Analisa Perbandingan Biaya Pembuatan Pelat Beton Sistem Konvensional Dengan Sistem Boundeck Pada Pembangunan Gedung Kuliah Bersama Politeknik Negeri Fakfak - Muhammad Yunus, Budi Djatmiko 
7. Membuat perbandingan biaya tiap komponen pelat lantai beton berdasarkan Rencana Anggaran Biaya (RAB) pekerjaan pelat lantai sistem konvensional dan sistem boundeck.

8. Menganalisa komponen apa saja yang mempengaruhi biaya pembuatan pelat lantai beton sistem konvensional dan sistem boundeck.

\section{Hasil dan Pembahasan}

\subsection{Volume Pekerjaan Pelat Lantai Beton}

Perhitungan volume pekerjaan pelat lantai beton berdasarkan DED (Detail Engineering Design) Pembangunan Gedung Kuliah Bersama Politeknik Negeri Fakfak seperti pada Gambar 1 dan Gambar 2 di bawah ini:

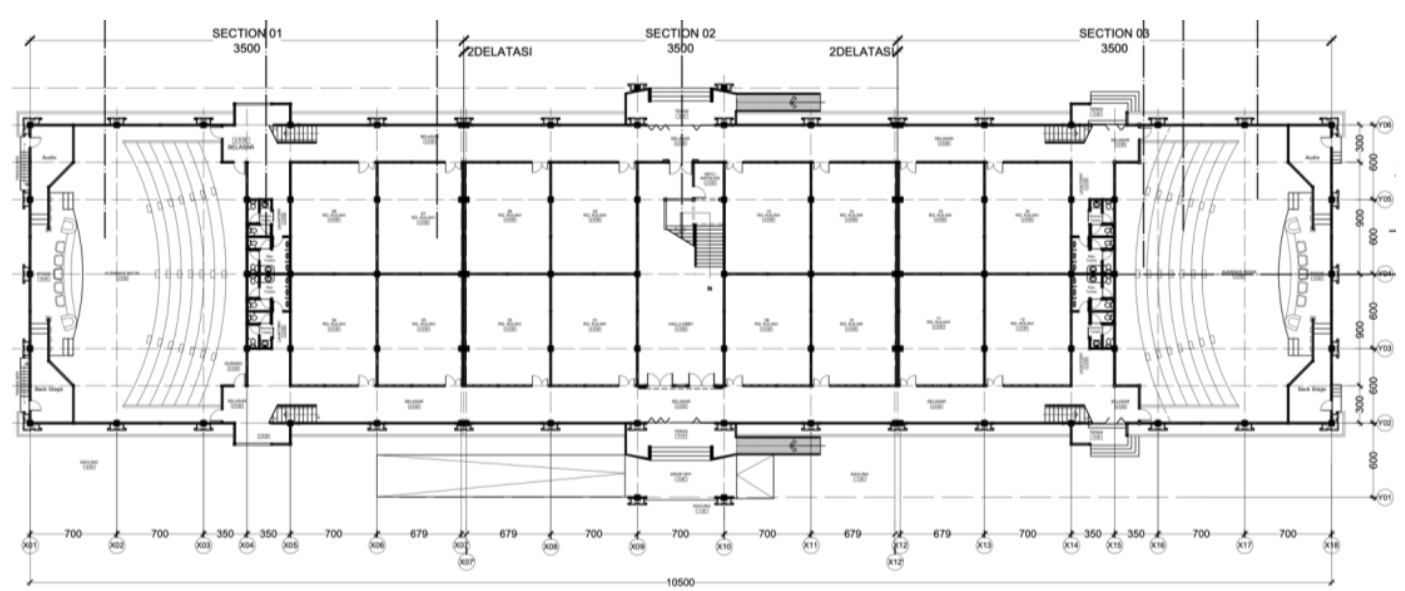

Gambar 1 Denah gedung kuliah bersama lantai 01

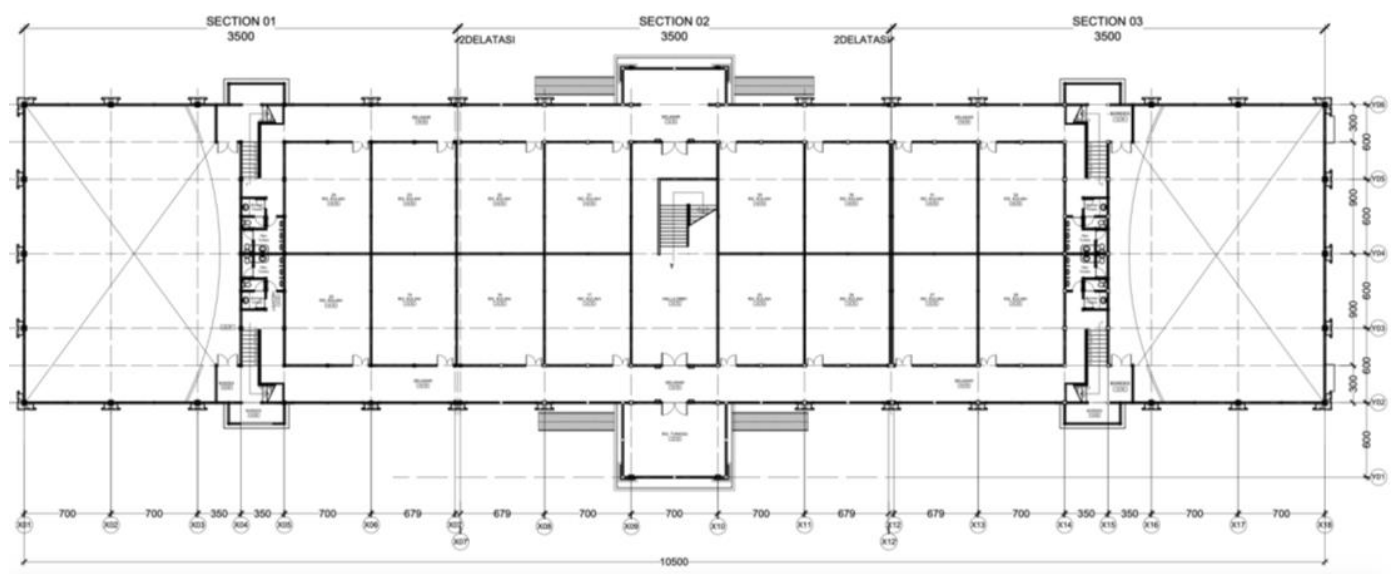

Gambar 2 Denah gedung kuliah bersama lantai 02

Berdasarkan Gambar 1 dan Gambar 2 di atas, diperoleh volume pekerjaan pelat lantai beton yang diisajikan pada Tabel 1 .

Analisa Perbandingan Biaya Pembuatan Pelat Beton Sistem Konvensional Dengan Sistem Boundeck Pada Pembangunan Gedung Kuliah Bersama Politeknik Negeri Fakfak - Muhammad Yunus, Budi Djatmiko 
Tabel 1 Rekapitulasi volume pekerjaan pelat lantai beton

\begin{tabular}{lllcccccc}
\hline & \multicolumn{2}{c}{ Uraian } & & \multicolumn{3}{c}{ Sat } & \multicolumn{3}{c}{ Boundeck } & \multicolumn{3}{c}{ Konvensional } \\
No & Pekerjaan & Section 1 & Section 2 & Section 3 & Section 1 & Section 2 & Section 3 \\
\hline 1. & $\begin{array}{l}\text { Bekisting dan } \\
\text { Boundeck }\end{array}$ & $\mathrm{m}^{2}$ & $1.579,93$ & $1.093,70$ & 647.62 & $1.579,93$ & $1.093,70$ & 647.62 \\
\hline 2. & $\begin{array}{l}\text { Pembesian } \\
\text { dan Wiremesh }\end{array}$ & $\mathrm{Kg}$ & $13.841,96$ & $10.709,34$ & $7.208,01$ & $13.841,96$ & $10.709,34$ & $7.208,01$ \\
\hline 3. & $\begin{array}{l}\text { Beton Pelat } \\
\text { Lantai }\end{array}$ & $\mathrm{m}^{3}$ & 189.59 & 131.24 & 80.95 & 189.59 & 131,24 & 80.95 \\
\hline
\end{tabular}

\subsection{Analisa Harga Satuan Pekerjaan}

Penyusunan Analisa Harga Satuan Pekerjaan merujuk ke SNI Tahun 2008 dan Tahun 2016 serta Daftar Harga Bahan dan Upah Kabupaten Fakfak Tahun 2019. Analisa Harga Satuan Pekerjaan yang akan dianalisa meliputi harga satuan komponen pekerjaan bekisting, pekerjaan pembesian dan pekerjaan beton K-250.

\subsubsection{Pekerjaan bekisting}

Untuk analisa harga satuan pekerjaan bekisting masing-masing untuk sistem pelat beton konvensional dan sistem pelat beton boundeck dapat dilihat pada Tabel 2 dan Tabel 3.

Tabel 2 Analisa harga satuan pekerjaan per $\mathrm{m}^{2}$ bekisting sistem konvensional

\begin{tabular}{|c|c|c|c|c|c|}
\hline No. & Uraian & Sat & Koefisien & $\begin{array}{c}\text { Harga Satuan } \\
\text { ( Rp ) }\end{array}$ & $\begin{array}{c}\text { Jumlah Harga } \\
(\text { Rp })\end{array}$ \\
\hline $\mathrm{A}$ & Tenaga Kerja & & & & \\
\hline 1 & Pekerja & $\mathrm{Oh}$ & 0.660 & $\begin{array}{ll}\mathrm{Rp} & 120.080 .00 \\
\end{array}$ & $79.252,80$ \\
\hline 2 & Tukang Kayu & $\mathrm{Oh}$ & 0.330 & $154,903.20$ & $51.118,06$ \\
\hline 3 & Kepala Tukang & $\mathrm{Oh}$ & 0.033 & $160.907,20$ & $5.309,94$ \\
\hline \multirow[t]{2}{*}{4} & Mandor & $\mathrm{Oh}$ & 0.033 & $166.310,80$ & $5.488,26$ \\
\hline & & & & Jumlah Harga Upah & $\begin{array}{ll}\mathrm{Rp} & 141.169,05\end{array}$ \\
\hline $\mathrm{B}$ & Bahan & & & & \\
\hline 1 & Kayu Klas II & $\mathrm{m}^{3}$ & 0.040 & Rp 3.052.308,00 & $\begin{array}{ll}\mathrm{Rp} & 122.092,32 \\
\end{array}$ \\
\hline 2 & Paku $5-12 \mathrm{~cm}$ & $\mathrm{~kg}$ & 0.400 & Rp $\quad 34,287.59$ & $\begin{array}{ll}\mathrm{Rp} & 13.715,04 \\
\end{array}$ \\
\hline 3 & Minyak Bekisting & ltr & 0.200 & $19,076.93$ & $3,815.39$ \\
\hline 4 & Balok kayu Klas II & $\mathrm{m}^{3}$ & 0.018 & $\begin{array}{ll}\mathrm{Rp} & 5.403 .311,90 \\
\end{array}$ & $97.259,61$ \\
\hline 5 & Plywood tebal $9 \mathrm{~mm}$ & $\mathrm{lbr}$ & 0.350 & $\begin{array}{ll}\mathrm{Rp} & 219,206.59 \\
\end{array}$ & $\begin{array}{ll}\mathrm{Rp} & 76.722,31 \\
\end{array}$ \\
\hline \multirow[t]{2}{*}{6} & Dolken Kayu panjang $4 \mathrm{~m}$ & btg & 6.000 & $\mathrm{Rp} \quad 33,880.62$ & $\begin{array}{ll}\mathrm{Rp} & 203.288,71 \\
\end{array}$ \\
\hline & & & & Jumlah Harga Bahan & Rp 516.888,37 \\
\hline \multirow[t]{2}{*}{$\mathrm{C}$} & Peralatan & & & $\mathrm{Rp}-$ & $\mathrm{Rp}-$ \\
\hline & & & & Jumlah Harga Peralatan & $\mathrm{Rp}-$ \\
\hline $\mathrm{D}$ & $\operatorname{Jumlah}(a+b+c)$ & & & & Rp $\quad 658.057,42$ \\
\hline $\mathrm{E}$ & Overhead \& Profit ( $10 \%$ & & & & Rp $\quad 65.805,74$ \\
\hline $\mathrm{F}$ & Harga satuan pekerjaan ( c & e ) & & & $\mathrm{Rp} 723.863,17$ \\
\hline
\end{tabular}

Tabel 3 Analisa harga satuan pekerjaan per $\mathrm{m}^{2}$ bekisting sistem boundeck

\begin{tabular}{clrrrr}
\hline No. & \multicolumn{1}{c}{ Uraian } & Sat. & Koefisien & Harga Satuan (Rp.) & $\begin{array}{c}\text { Jumlah Harga } \\
\text { (Rp.) }\end{array}$ \\
\hline A. & Tenaga Kerja & & & & \\
\hline 1 & Pekerja & Oh & 0.660 & Rp. $120.080,00$ & Rp. 79.252 .80 \\
\hline 2 & Tukang Kayu & Oh & 0.330 & Rp. $130.800,00$ & Rp. 51.118 .06 \\
\hline 3 & Kepala Tukang & Oh & 0.033 & Rp. 160.310,80 & Rp. 5.309 .94 \\
\hline 4 & Mandor & Oh & 0.033 & Rp. 166.310.80 & Rp. 5.488 .26 \\
\hline & & & Jumlah Harga Upah & Rp. 141.169 .05 \\
\hline
\end{tabular}

Analisa Perbandingan Biaya Pembuatan Pelat Beton Sistem Konvensional Dengan Sistem Boundeck Pada Pembangunan Gedung Kuliah Bersama Politeknik Negeri Fakfak - Muhammad Yunus, Budi Djatmiko 


\begin{tabular}{|c|c|c|c|c|c|}
\hline B. & Bahan & & & & \\
\hline 1 & Kayu Klas III & $\mathrm{m}^{3}$ & 0.040 & Rp. 3.052.308,00 & Rp. 122.092,32 \\
\hline 2 & Paku $5-12 \mathrm{~cm}$ & $\mathrm{Kg}$ & 0.400 & $\begin{array}{ll}\text { Rp. } & 34.287,59 \\
\end{array}$ & $\begin{array}{ll}\text { Rp. } & 13.715,04 \\
\end{array}$ \\
\hline 3 & Minyak Bekisting klas II & Ltr & 0.200 & $19.076,93$ & $\mathrm{Rp} .3 .815 .39$ \\
\hline 4 & Balok Kayu Klas II & $\mathrm{m}^{3}$ & 0.018 & Rp. 5.403.311,90 & Rp. 97.259 .61 \\
\hline 5 & Plat Boundeck $0.75 \mathrm{~mm}$ & $\mathrm{~m}^{2}$ & 1.050 & $\begin{array}{ll}\text { Rp. } & 278.617,50 \\
\end{array}$ & Rp. $92.548,38$ \\
\hline \multirow[t]{2}{*}{6} & Dolken Kayu panjang $4 \mathrm{~m}$ & Btg & 1.750 & $\begin{array}{ll}\text { Rp. } & 33.880,62 \\
\end{array}$ & Rp. $59.291,00$ \\
\hline & & & & Jumlah Harga Bahan & Rp. 588.720,81 \\
\hline \multirow[t]{2}{*}{ C. } & Peralatan & & & Rp. - & Rp. - \\
\hline & & & & Jumlah Harga Peralatan & Rp. - \\
\hline D. & Jumlah Harga ( A + B + & & & & Rp. $729.890,86$ \\
\hline E. & Overhead \& Profit (10\% & & & & $\begin{array}{ll}\text { Rp. } & 72.989,09 \\
\end{array}$ \\
\hline F. & Harga Satuan Pekerjaan & $+\mathrm{E})$ & & & Rp. $802.879,95$ \\
\hline
\end{tabular}

\subsubsection{Pekerjaan pembesian}

Untuk analisa harga satuan pekerjaan pembesian masing-masing untuk sistem pelat beton konvensional dan sistem pelat beton boundeck dapat dilihat pada Tabel 4 dan Tabel 5.

Tabel 4 Analisa harga satuan pekerjaan per kg pembesian sistem konvensional

\begin{tabular}{|c|c|c|c|c|c|c|}
\hline No. & Uraian & Sat & Koefisien & $\begin{array}{c}\text { Harga Satuan } \\
\text { ( Rp ) }\end{array}$ & \multicolumn{2}{|c|}{$\begin{array}{c}\text { Jumlah Harga } \\
(\text { ( Rp ) }\end{array}$} \\
\hline $\mathrm{A}$ & Tenaga Kerja & & & & & \\
\hline 1 & Pekerja & oh & 0.070 & Rp $120.080,00$ & $\mathrm{Rp}$ & $8.405,60$ \\
\hline 2 & Tukang Besi & oh & 0.070 & Rp $154.903,20$ & $\mathrm{Rp}$ & $10.843,22$ \\
\hline 3 & Kepala Tukang & oh & 0.007 & Rp $160.907,20$ & $\mathrm{Rp}$ & $1.126,35$ \\
\hline \multirow[t]{2}{*}{4} & Mandor & oh & 0.004 & $\mathrm{Rp} 166.310,80$ & $\mathrm{Rp}$ & 665,24 \\
\hline & & & & Jumlah Harga Upah & $\mathrm{Rp}$ & $21.040,42$ \\
\hline B & Bahan & & & & & \\
\hline 1 & Besi Beton ( Polos/Ulir ) & $\mathrm{Kg}$ & 10.500 & Rp $21,489.02$ & $\mathrm{Rp}$ & $225,634.73$ \\
\hline \multirow[t]{2}{*}{2} & Kawat Beton & $\mathrm{Kg}$ & 0.150 & $\begin{array}{rr}\mathrm{Rp} & 32,303.59 \\
\end{array}$ & $\mathrm{Rp}$ & $4,845.54$ \\
\hline & & & & Jumlah Harga Bahan & $\mathrm{Rp}$ & $230,480.27$ \\
\hline \multirow[t]{2}{*}{$\mathrm{C}$} & Peralatan & & & $\mathrm{Rp}-$ & $\mathrm{Rp}-$ & \\
\hline & & & & Jumlah Harga Peralatan & $\mathrm{Rp}-$ & \\
\hline $\mathrm{D}$ & $\operatorname{Jumlah}(\mathrm{A}+\mathrm{B}+\mathrm{C})$ & & & & $\mathrm{Rp}$ & $251.520,68$ \\
\hline $\mathrm{E}$ & Overhead \& Profit ( $10 \%$ & D) & & & $\mathrm{Rp}$ & $25.152,07$ \\
\hline $\mathrm{F}$ & Harga Satuan Pekerjaan & $+E)$ & untuk / & $10 \mathrm{~kg}$ & $\mathrm{Rp}$ & $276.672,75$ \\
\hline G & Harga Satuan Pekerjaan & $10)$ & untuk / & $1 \mathrm{~kg}$ & $\mathrm{Rp}$ & $27.667,28$ \\
\hline
\end{tabular}

Tabel 5 Analisa harga satuan pekerjaan per $\mathrm{kg}$ pembesian sistem boundeck

\begin{tabular}{|c|c|c|c|c|c|}
\hline No. & Uraian & Sat & Koefisien & $\begin{array}{l}\text { Harga Satuan } \\
\text { ( Rp ) }\end{array}$ & $\begin{array}{c}\text { Jumlah Harga } \\
\text { ( Rp ) }\end{array}$ \\
\hline A & Tenaga Kerja & & & & \\
\hline 1 & Pekerja & Oh & 0.025 & Rp $120.080,00$ & Rp $3.002,00$ \\
\hline 2 & Tukang Besi & $\mathrm{Oh}$ & 0.025 & Rp $154.903,20$ & $\mathrm{Rp} \quad 3.872,58$ \\
\hline 3 & Kepala Tukang & $\mathrm{Oh}$ & 0.025 & Rp $160.907,20$ & $\begin{array}{ll}\mathrm{Rp} & 4.022,68 \\
\end{array}$ \\
\hline \multirow[t]{2}{*}{4} & Mandor & $\mathrm{Oh}$ & 0.001 & Rp $166.310,80$ & $\begin{array}{ll}\mathrm{Rp} & 166.31 \\
\end{array}$ \\
\hline & & & & Jumlah Harga Upah & Rp $11.063,57$ \\
\hline $\mathrm{B}$ & Bahan & & & & \\
\hline 1 & $\begin{array}{l}\text { Jaring Kawat Baja Dilas } \\
\text { (Wiremesh) }\end{array}$ & $\mathrm{Kg}$ & 10.200 & Rp $24.456,43$ & Rp $249.455,54$ \\
\hline \multirow[t]{2}{*}{2} & Kawat Beton & $\mathrm{Kg}$ & 0.050 & $\begin{array}{rr}\mathrm{Rp} & 32,303.59 \\
\end{array}$ & $\begin{array}{ll}\mathrm{Rp} & 1,615.18 \\
\end{array}$ \\
\hline & & & & Jumlah Harga Bahan & Rp 251.070,71 \\
\hline \multirow[t]{2}{*}{$\mathrm{C}$} & Peralatan & & & $\mathrm{Rp}-$ & $\mathrm{Rp}-$ \\
\hline & & & & Jumlah Harga Peralatan & $\mathrm{Rp}-$ \\
\hline $\mathrm{D}$ & Jumlah $(A+B+C)$ & & & & Rp 262.134,29 \\
\hline
\end{tabular}

Analisa Perbandingan Biaya Pembuatan Pelat Beton Sistem Konvensional Dengan Sistem Boundeck Pada Pembangunan Gedung Kuliah Bersama Politeknik Negeri Fakfak - Muhammad Yunus, Budi Djatmiko 


\begin{tabular}{|c|c|c|c|}
\hline $\mathrm{E}$ & Overhead \& Profit ( $10 \%$ x D ) & & $26.213,43$ \\
\hline $\mathrm{F}$ & Harga satuan Pekerjaan $(D+E)$ & untuk / $10 \mathrm{~kg}$ & Rp 288.347,71 \\
\hline $\bar{G}$ & Harga Satuan Pekerjaan ( F/ 10 ) & untuk / $1 \mathrm{~kg}$ & $\begin{array}{ll}\mathrm{Rp} & 28.834,77\end{array}$ \\
\hline
\end{tabular}

\subsubsection{Pekerjaan pembetonan}

Untuk analisa harga satuan pekerjaan pembetonan masing-masing untuk sistem pelat beton konvensional dan sistem pelat beton boundeck dapat dilihat pada Tabel 6 dan Tabel 7.

Tabel 6 Analisa harga satuan pekerjaan per $\mathrm{m}^{3}$ beton K-250 sistem konvensional

\begin{tabular}{|c|c|c|c|c|c|c|}
\hline No. & Uraian & Sat & Koefisien & \multicolumn{2}{|c|}{$\begin{array}{l}\text { Harga Satuan } \\
\text { ( Rp ) }\end{array}$} & $\begin{array}{c}\text { Jumlah Harga } \\
(\mathbf{R p})\end{array}$ \\
\hline $\mathrm{A}$ & \multicolumn{6}{|l|}{ Tenaga Kerja } \\
\hline 1 & Pekerja & $\mathrm{Oh}$ & 1.650 & $\mathrm{Rp}$ & $120.080,00$ & $198,132.00$ \\
\hline 2 & Tukang Batu & $\mathrm{Oh}$ & 0.275 & $\mathrm{Rp}$ & $154.903,20$ & $\begin{array}{ll}\text { Rp. } & 37.244,80\end{array}$ \\
\hline 3 & Kepala Tukang & $\mathrm{Oh}$ & 0.025 & $\mathrm{Rp}$ & $160.907,20$ & $4.022,68$ \\
\hline \multirow[t]{2}{*}{4} & Mandor & $\mathrm{Oh}$ & 0.080 & $\mathrm{Rp}$ & $166.310,80$ & $\begin{array}{ll}\text { Rp. } & 13.304,86 \\
\end{array}$ \\
\hline & & & & \multicolumn{2}{|c|}{ Jumlah Harga Upah } & Rp. $\quad 252.684,86$ \\
\hline $\mathrm{B}$ & Bahan & & & & & \\
\hline 1 & Semen Portland & $\mathrm{Kg}$ & 280.00 & Rp. & $3.541,95$ & Rp. $991.747,16$ \\
\hline 2 & Pasir Beton & $\mathrm{M}^{3}$ & 0.45 & Rp. & $1.379 .897,58$ & $\begin{array}{ll}\text { Rp. } & 620.953,91 \\
\end{array}$ \\
\hline \multirow[t]{2}{*}{3} & Kerikil (maks $30 \mathrm{~mm}$ ) & $\mathrm{M}^{3}$ & 0.90 & $\mathrm{Rp}$. & $2.635 .159,25$ & Rp. 2.371.643,32 \\
\hline & & & & Jumlah & Harga Bahan & Rp. 3.984.643,39 \\
\hline \multirow[t]{2}{*}{$\mathrm{C}$} & Peralatan & & & $\mathrm{Rp}-$ & & $\mathrm{Rp}-$ \\
\hline & & & & Jumlah $\mathrm{H}_{2}$ & ga Peralatan & $\mathrm{Rp}-$ \\
\hline $\mathrm{D}$ & \multicolumn{3}{|c|}{ Jumlah Harga $(A+B+C)$} & & & Rp. 4.237.028,73 \\
\hline $\mathrm{E}$ & \multirow{2}{*}{\multicolumn{3}{|c|}{ Overhead \& Profit (10\% x D) }} & & & $\begin{array}{ll}\text { Rp. } & 423.702,87 \\
\end{array}$ \\
\hline $\mathrm{F}$ & & & & $\left.\mathrm{m}^{3}\right)$ & & Rp. $4.660 .731,60$ \\
\hline
\end{tabular}

Tabel 7 Analisa harga satuan pekerjaan per $\mathrm{m}^{3}$ beton $\mathrm{K}-250$ sistem boundeck

\begin{tabular}{|c|c|c|c|c|c|c|}
\hline No. & Uraian & Sat & Koefisien & \multicolumn{2}{|c|}{$\begin{array}{l}\text { Harga Satuan } \\
\quad(\text { Rp })\end{array}$} & $\begin{array}{c}\text { Jumlah Harga } \\
\text { ( Rp ) }\end{array}$ \\
\hline A & Tenaga Kerja & & & & & \\
\hline 1 & Pekerja & Oh & 1.650 & $\mathrm{Rp}$ & $120.080,00$ & $\begin{array}{ll}\text { Rp. } & 198,132.00\end{array}$ \\
\hline 2 & Tukang Batu & Oh & 0.275 & $\mathrm{Rp}$ & $154.903,20$ & $\begin{array}{ll}\text { Rp. } & 37.244,80 \\
\end{array}$ \\
\hline 3 & Kepala Tukang & Oh & 0.025 & $\mathrm{Rp}$ & $160.907,20$ & $4.022,68$ \\
\hline \multirow[t]{2}{*}{4} & Mandor & Oh & 0.080 & $\mathrm{Rp}$ & $166.310,80$ & $\begin{array}{ll}\text { Rp. } & 13.304,86 \\
\end{array}$ \\
\hline & & & & \multicolumn{2}{|c|}{ Jumlah Harga Upah } & $\begin{array}{ll}\text { Rp. } & 252.684,86 \\
\end{array}$ \\
\hline $\mathrm{B}$ & Bahan & & & & & \\
\hline 1 & Semen Portland & $\mathrm{Kg}$ & 280.00 & & $3.541,95$ & Rp. $991.747,16$ \\
\hline 2 & Pasir Beton & $\mathrm{M}^{3}$ & 0.45 & & $1.379 .897,58$ & $\begin{array}{ll}\text { Rp. } & 620.953,91 \\
\end{array}$ \\
\hline \multirow[t]{2}{*}{3} & Kerikil (maks $30 \mathrm{~mm}$ ) & $\mathrm{M}^{3}$ & 0.90 & & $2.635 .159,25$ & Rp. $2.371 .643,32$ \\
\hline & & & & Jumla & Jarga Bahan & Rp. 3.984.643,39 \\
\hline \multirow[t]{2}{*}{$\mathrm{C}$} & Peralatan & & & $\mathrm{Rp}$ & & $\mathrm{Rp}-$ \\
\hline & & & & Jumlah H & ga Peralatan & $\mathrm{Rp}-$ \\
\hline $\mathrm{D}$ & \multicolumn{2}{|c|}{ Jumlah Harga $(A+B+C)$} & & & & Rp. 4.237.028,73 \\
\hline $\mathrm{E}$ & \multicolumn{2}{|c|}{ Overhead \& Profit (10\% x D) } & & & & Rp. $\quad 423.702,87$ \\
\hline $\mathrm{F}$ & \multicolumn{2}{|c|}{ Harga Satuan Pekerjaan (D + E ) } & & \multicolumn{2}{|l|}{$\left(\mathrm{m}^{3}\right)$} & Rp. $4.660 .731,60$ \\
\hline
\end{tabular}

\subsection{Pembahasan}

Hasil Analisa Harga Satuan Pekerjaan yang telah disusun di atas, selanjutnya akan dibandingkan tiap komponen pelat lantai beton baik sistem konvensional maupun sistem boundeck.

Analisa Perbandingan Biaya Pembuatan Pelat Beton Sistem Konvensional Dengan Sistem Boundeck Pada Pembangunan Gedung Kuliah Bersama Politeknik Negeri Fakfak - Muhammad Yunus, Budi Djatmiko 


\subsubsection{Pekerjaan bekisting}

Dari hasil analisa harga satuan pekerjaan pembuatan pelat lantai beton menggunakan sistem konvensional dan sistem boundeck pada komponen bekisting diperoleh perbandingan selisih biaya yang dapat dilihat pada Tabel 8 .

Tabel 8 Perbandingan biaya komponen bekisting

\begin{tabular}{clccccc}
\hline \multirow{2}{*}{ No } & \multirow{2}{*}{ Uraian Pekerjaan } & \multirow{2}{*}{ Sat } & \multicolumn{2}{c}{ Komponen Bekisting } & Jumlah Harga \\
\cline { 3 - 5 } & & Volume & Harga Satuan & (Rp) \\
\hline 1 & Sistem Boundeck & $\mathrm{M}^{2}$ & $3.348,25$ & Rp. $802.879,95$ & Rp. $2.688 .242 .795,33$ \\
\hline 2 & Sistem Konvensional & $\mathrm{M}^{2}$ & $3.348,25$ & Rp. $723.863,17$ & Rp. $2.423 .674 .848,56$ \\
\hline
\end{tabular}

Dari Tabel 8 di atas dapat dibuat grafik perbandingan komponen pekerjaan bekisting sistem konvensional dan sistem boundeck pada Gambar 3.

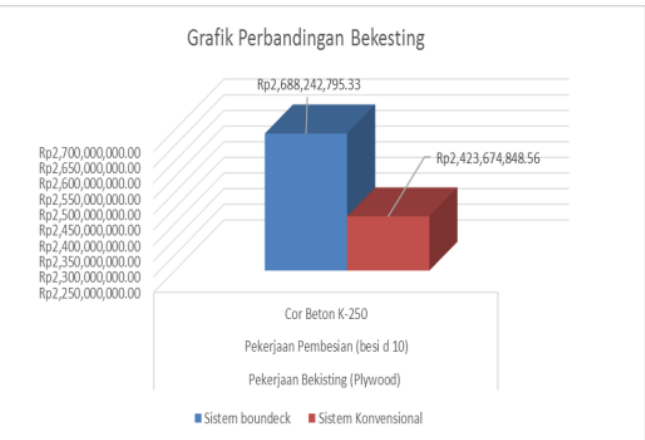

Gambar 3 Perbandingan biaya komponen bekisting

Dari grafik pada Gambar 3 diatas dapat diketahui biaya komponen pekerjaan bekisting sistem boundeck dan sistem konvensional memiliki selisih sebesar \pm Rp. 264.567.000,00 atau sebesar 9,84\%, di mana komponen bekisting sistem boundeck lebih lebih besar di bandingkan dengan sistem konvensional. Perbedaan ini disebabkan oleh perbedaan komponen bahan yang digunakan, untuk pelat beton sistem konvensional menggunakan plywood/multipleks sedangkan untuk sistem boundeck menggunakan plat boundeck tebal $0,75 \mathrm{~mm}$.

\subsubsection{Pekerjaan pembesian}

Dari hasil analisa harga satuan pekerjaan pembuatan pelat lantai beton menggunakan sistem konvensional dan sistem boundeck pada komponen pembesian diperoleh perbandingan selisih biaya yang dapat dilihat pada Tabel 9.

Tabel 9 Perbandingan biaya komponen pembesian

\begin{tabular}{|c|c|c|c|c|c|}
\hline \multirow{2}{*}{ No } & \multirow{2}{*}{ Uraian Pekerjaan } & \multirow{2}{*}{ Sat } & \multicolumn{2}{|c|}{ Pekerjaan Pembesian } & \multirow{2}{*}{$\begin{array}{c}\text { Jumlah Harga } \\
\text { (Rp) }\end{array}$} \\
\hline & & & Volume & AHSP & \\
\hline 1 & Sistem Boundeck & $\mathrm{Kg}$ & $31,759.31$ & Rp. $28.834,77$ & Rp. $\quad 915.772 .443 .66$ \\
\hline 2 & Sistem Konvensional & $\mathrm{Kg}$ & $31,759.31$ & Rp. $27.667,28$ & $878.693 .574,43$ \\
\hline
\end{tabular}

Dari Tabel 9 di atas dapat dibuat grafik perbandingan komponen pekerjaan pembesian sistem konvensional dan sistem boundeck pada Gambar 4.

Analisa Perbandingan Biaya Pembuatan Pelat Beton Sistem Konvensional Dengan Sistem Boundeck Pada Pembangunan Gedung Kuliah Bersama Politeknik Negeri Fakfak - Muhammad Yunus, Budi Djatmiko 


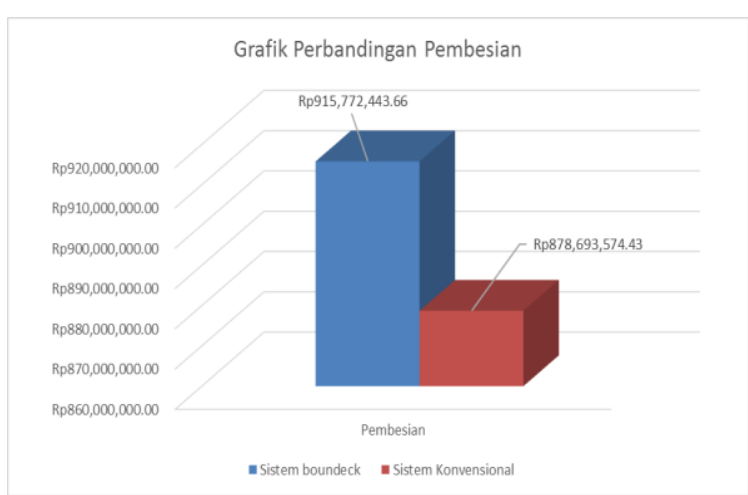

Gambar 4 Perbandingan biaya komponen pembesian

Dari grafik pada Gambar 4 di atas dapat diketahui biaya komponen pekerjaan bekisting sistem boundeck dan sistem konvensional memiliki selisih sebesar \pm Rp. 37.078.000,00 atau sebesar 4,04\%, di mana komponen pekerjaan pembesian sistem boundeck lebih kecil dibandingkan dengan sistem konvensional. Perbedaan ini disebabkan oleh perbedaan komponen bahan dan, untuk pelat beton sistem konvensional menggunakan besi tulangan dan kawat beton sedangkan untuk sistem boundeck menggunakan besi jaring kawat baja

\subsubsection{Pekerjaan pembetonan}

Dari hasil analisa harga satuan pekerjaan pembuatan pelat lantai beton menggunakan sistem konvensional dan sistem boundeck pada komponen pembetonan diperoleh perbandingan selisih biaya pada Tabel 10 .

Tabel 10 Perbandingan biaya komponen pembetonan K-250

\begin{tabular}{llccccr}
\hline \multirow{2}{*}{ No } & \multirow{2}{*}{ Uraian Pekerjaan } & \multirow{2}{*}{ Sat } & \multicolumn{2}{c}{ Pekerjaan Pembetonan } & \multirow{2}{*}{ Jumlah Harga (Rp.) } \\
\cline { 3 - 5 } & & Volume & AHSP & \\
\hline 1 & Sistem Boundeck & $\mathrm{m}^{3}$ & 401.78 & Rp. $4.660 .731,60$ & Rp. $1,872,588,743.78$ \\
2 & Sistem Konvensional & $\mathrm{M}^{3}$ & 401.78 & Rp. 4.660.731,60 & Rp. $1,872,588,743.78$ \\
\hline
\end{tabular}

Dari Tabel 10 di atas dapat dibuat grafik perbandingan komponen pekerjaan pembetonan K-250 sistem konvensional dan sistem boundeck pada Gambar 5.

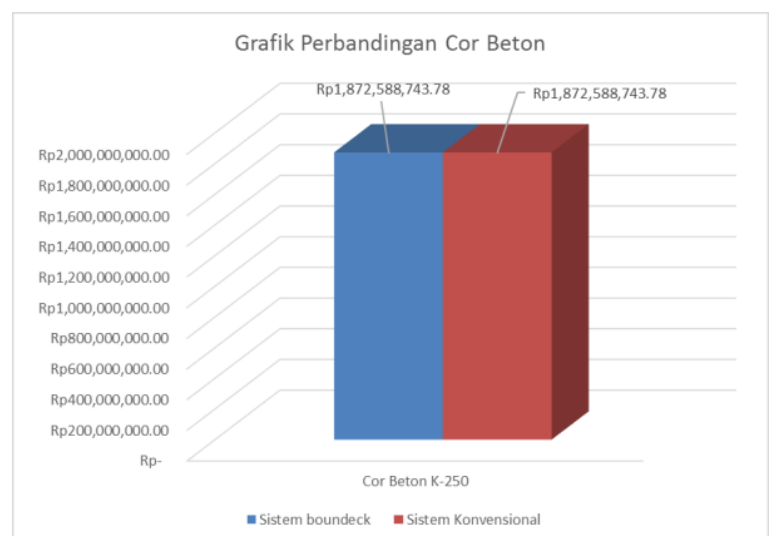

Gambar 5 Perbandingan biaya komponen pembetonan K-250

Analisa Perbandingan Biaya Pembuatan Pelat Beton Sistem Konvensional Dengan Sistem Boundeck Pada Pembangunan Gedung Kuliah Bersama Politeknik Negeri Fakfak - Muhammad Yunus, Budi Djatmiko 
Dari grafik pada Gambar 5 diatas dapat diketahui untuk biaya komponen pekerjaan pembetonan K-250 sistem boundeck dan sistem konvensional adalah sama atau tidak memiliki selisih, hal ini disebabkan komponen bahan dan tenaga kerja yang digunakan sama antara sistem konvensional dan sistem boundeck.

\subsubsection{Rencana anggaran biaya (RAB)}

Dalam menghitung Rencana Anggaran Biaya (RAB) tiap komponen pekerjaan pembuatan pelat lantai beton baik dengan metode sistem konvensional metode sistem boundeck, data-data yang dibutuhkan adalah volume pekerjaan dan analisa harga satuan tiap item pekerjaan. Untuk rekapitulasi Rincian Anggaran Biaya (RAB) pekerjaan pembuatan pelat lantai beton baik dengan metode sistem konvensional dan metode sistem boundeck dapat dilihat pada Tabel 11.

Tabel 11 Rencana anggaran biaya pekerjan pembuatanpelat lantai beton

\begin{tabular}{|c|c|c|c|c|c|c|}
\hline No. & Uraian Pekerjaan & Sat & Volume & $\begin{array}{l}\text { Harga Satuan } \\
\text { ( Rp. ) }\end{array}$ & & $\begin{array}{l}\text { Jumlah Harga } \\
\text { ( Rp. ) }\end{array}$ \\
\hline \multirow[t]{4}{*}{ A. } & Sistem Konvensional & & & & $\mathrm{Rp}$ & $5.174 .957 .166,77$ \\
\hline & a. $\quad$ Pekerjaan Bekisting & $\mathrm{m}^{2}$ & $3,348.25$ & $723.863,17$ & $\mathrm{Rp}$ & $2.423 .674 .848,56$ \\
\hline & $\begin{array}{l}\text { Pekerjaan Pembesian } \\
\text { (besi } \mathrm{d} 10)\end{array}$ & $\mathrm{kg}$ & $31,759.31$ & 27.667 .28 & $\mathrm{Rp}$ & $878.693 .574,43$ \\
\hline & Cor Beton K-250 & $\mathrm{m}^{3}$ & 401.78 & Rp 4.660.730,60 & $\mathrm{Rp}$ & $1.872 .588 .743,78$ \\
\hline \multirow[t]{4}{*}{ B. } & Sistem Boundeck & & & & $\mathrm{Rp}$ & $5.476 .603 .982,77$ \\
\hline & a. $\quad$ Pekerjaan Bekisting & $\mathrm{m}^{2}$ & $3,348.25$ & $802.879,95$ & $\mathrm{Rp}$ & $2.688 .242 .795,33$ \\
\hline & Pekerjaan Pembesian & $\mathrm{kg}$ & $31,759.31$ & $\mathrm{Rp} \quad 28.834,77$ & $\mathrm{Rp}$ & $915.772 .443,66$ \\
\hline & Cor Beton K-250 & $\mathrm{m}^{3}$ & 401.78 & $\operatorname{Rp} 4.660 .730,60$ & $\mathrm{Rp}$ & $1.872 .588 .743,78$ \\
\hline
\end{tabular}

Dari Tabel 11 dapat dibuat grafik perbandingan biaya masing-masing metode pada Gambar 6 berikut ini:

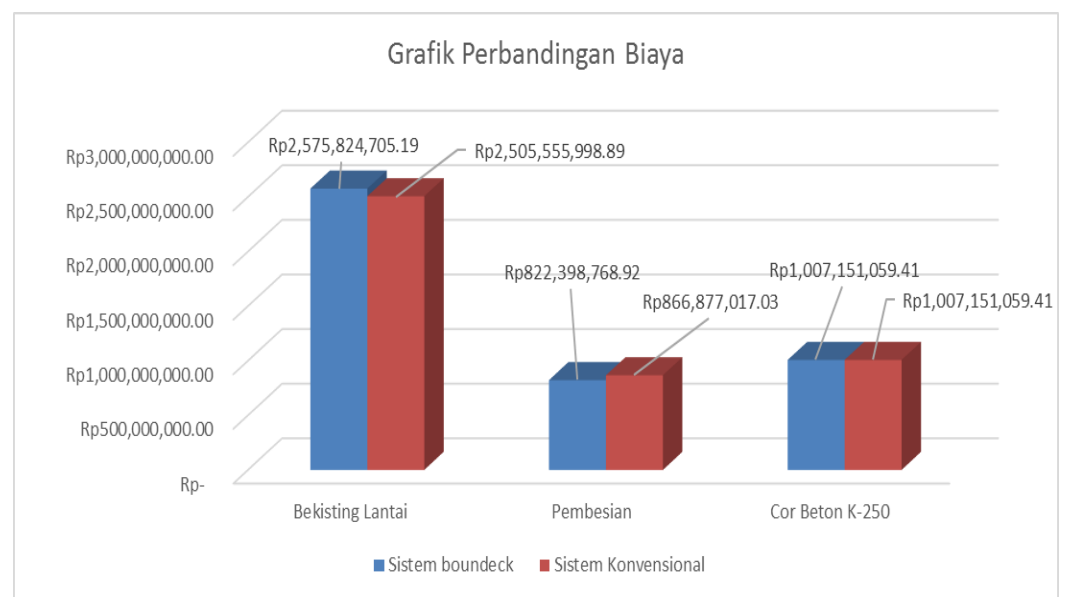

Gambar 6 Perbandingan biaya pembuatan pelat lantai beton

Dari grafik perbandingan pada Gambar 6 diatas dapat diketahui bahwa komponen biaya pekerjaan pembuatan pelat lantai beton yang berbeda adalah pada komponen pekerjaan bekisting dan komponen pembesian, sedangkan untuk komponen biaya pembetonan K-250 adalah sama untuk metode sistem konvensional maupun metode sistem boundeck.

Analisa Perbandingan Biaya Pembuatan Pelat Beton Sistem Konvensional Dengan Sistem Boundeck Pada Pembangunan Gedung Kuliah Bersama Politeknik Negeri Fakfak - Muhammad Yunus, Budi Djatmiko 


\section{Kesimpulan dan Saran}

\subsection{Kesimpulan}

Dari hasil analisa perbandingan biaya pembuatan pelat beton sistem konvensional dengan sistem boundeck pada Pembangunan Gedung Kuliah Bersama Politeknik Negeri Fakfak dapat disimpulkan bahwa biaya secara keseluruhan pekerjaan pembuatan pelat lantai beton dengan sistem boundeck sebesar Rp. 5.476.603.000,00 sedangkan untuk biaya pekerjaan pembuatan pelat lantai beton dengan sistem konvensional sebesar Rp. 5.174.957.000,00. Besarnya selisih biaya dari kedua sistem tersebut adalah sebesar Rp 301.646.000,00 atau sebesar 5,51\% lebih besar sistem boundeck dibandingkan sistem konvensional, hal ini disebabkan komponen dari pekerjaan bekisting dan pekerjaan pembesian pada sistem boundeck lebih mahal dibandingkan sistem kovensional. Berdasarkan hasil analisa, faktor-faktor yang mempengaruhi harga satuan komponen pekerjaan bekisting dan pekerjaan pembesian adalah harga bahan dan upah tenaga kerja yang digunakan pada masing-masing metode, baik sistem boundeck maupun sistem konvensional.

\subsection{Saran}

Hasil penelitian ini akan digunakan sebagai bahan masukan bagi kontraktor khususnya di wilayah Kabupaten Fakfak dalam pengambilan keputusan memilih metode pelaksanaan pekerjaan di lapangan. Selain itu, faktor waktu pelaksanaan perlu diteliti lebih lanjut untuk kedua metode di atas sehingga hasil penelitian dapat berupa kajian komprehensif yang lengkap.

\section{Daftar Kepustakaan}

Dinas PUPR2KP, 2019, Daftar Harga Bahan dan Upah Kabupaten Fakfak Tahun 2019, Kabupaten Fakfak

Gursal, A. A. P., Tjakra, J., \& Mangare, J. B., 2018, Analisis Efisiensi Biaya Dan Waktu Pelat Lantai Beton Bertulang Konvensional Terhadap Pelat Lantai Bondek, Tekno, 16(70), 77-82.

Peraturan Menteri Pekerjaan Umum dan Perumahan Rakyat No. 28/PRT/M/2016, 2016, Analisis Harga Satuan Pekerjaan Bidang Pekerjaan Umum

SNI 7394:2008., 2008, Tata Cara Perhitungan Harga Satuan Pekerjaan Beton untuk Konstruksi Bangunan Gedung dan Perumahan. Jakarta: Badan Standardisasi Nasional

Uji, A. T., Wisal, H. W., \& Latif, R. U, 2012, Perbandingan Biaya Pelaksanaan Pelat Beton Menggunakan Boundeck dan Pelat Konvensional Pada Gedung Graha Suraco, Teknik Sipil Universitas Hasanuddin, 1-25.

Widiasanti, I., \& Lenggogeni. 2013, Manajemen Konstruksi, Bandung, PT. Remaja Rosdakarya.

Copyright (c) Muhammad - Yunus

Analisa Perbandingan Biaya Pembuatan Pelat Beton Sistem Konvensional Dengan Sistem Boundeck Pada Pembangunan Gedung Kuliah Bersama Politeknik Negeri Fakfak - Muhammad Yunus, Budi Djatmiko 